Original article

Section: Food Quality and Functionality

\title{
Influence of a Sulphur Dioxide Active Storage System on the Quality of Ribes rubrum L. Berries
}

\author{
Luca Brondino ${ }^{\circledR}$, Davide Cadario ${ }^{\circledR}$, Nicole Roberta Giuggioli* $*$ () \\ Department of Agricultural Forest and Food Sciences (DISAFA), University of Turin, \\ Largo Paolo Braccini 2 - Grugliasco 10095 Torino, Italy
}

Key words: red currant, storage, modified atmosphere packaging, $\mathrm{SO}_{2}$, taste

\begin{abstract}
The aim of this study was to evaluate the post-harvest changes in the quality of red currants (Ribes rubrum L.) cv. 'Rovada' after 60 days of storage under modified atmosphere packaging (MAP) conditions. The storage unit was a pallet, and two treatments were performed. The $\mathrm{CO}_{2}-\mathrm{MAP}$ treatment was used as a control, while the $\mathrm{SO}_{2}$-MAP treatment was $\mathrm{CO}_{2}-\mathrm{MAP}$ plus $\mathrm{SO}_{2}$. The initial gas composition was $15.0 \mathrm{kPa} \mathrm{O}_{2}$ and $10.0 \mathrm{kPa} \mathrm{CO}_{2}$ inside all MAPs, while $\mathrm{SO}_{2}$-generating active sheets were added to pellets in $\mathrm{SO}_{2}$-MAP treatment. Weight loss, total soluble solid content, titratable acidity, total phenolic and anthocyanin contents, antioxidant activity, microbial count, and visual and sensorial appearance were monitored after 30 and 60 days. The results showed that berries stored with $\mathrm{SO}_{2}$ maintained the quality parameters for up to 60 days. Exposure to $\mathrm{SO}_{2}$ was effective in controlling yeast evolution, reducing the population both at 30 and 60 days at one and two orders of magnitude, respectively. Red currants stored under $\mathrm{SO}_{2} \mathrm{MAP}$ obtained better visual quality score compared to $\mathrm{CO}_{2}$ MAP-treated berries throughout storage.

Active emitters of $\mathrm{SO}_{2}$, such as those proposed in this study, can be promising solutions to improve the post-harvest storage of red currants and the berries marketability.
\end{abstract}

\section{INTRODUCTION}

Red currants, belonging to the Ribes genus of the Saxifragaceae family, are minor crops among berries. They are berry-bearing deciduous shrubs mainly consumed as processed in juices, jams, jellies, syrups, marinades, and wines [Kampuss \& Pedersen, 2003; Stępniowska et al., 2016]. Consumption of fresh red currants is largely related to visual appearance, and raceme and stalk freshness are the main quality indices of shelf life. 'Jonkheer van Tets', 'Rondom', 'Rovada', 'Rosetta', 'Rotet', 'Jonifer', 'Laxton no. 1', 'Red Lake', 'Stanza', and 'Laxton's Perfection Red Dutch' are the most common red currant cultivars grown in Europe, where Poland is the most important producer [www.freshplaza.com]. Similar to other berries, red currants (Ribes rubrum L.) are important species for the human diet, especially due to the highest capacity to scavenge free radicals [Laczkó-Zöld et al., 2018; Orsavová et al., 2019]. Vitamin C (ascorbic acid) is well known to be the most important free radical scavenger, with average content in fresh berries reported at $41 \mathrm{mg} / 100 \mathrm{~g}$ [Talcott, 2007]. Red currants are also an important source of macroand microelements (349.90 mg P; 1,876.94 mg K; $8.25 \mathrm{mg} \mathrm{Na}$; $281.08 \mathrm{mg} \mathrm{Ca} ; 1.18 \mathrm{mg} \mathrm{Mn} ; 94.43 \mathrm{mg} \mathrm{Mg} ; 3.73 \mathrm{mg} \mathrm{Fe}$ and $2.41 \mathrm{mg} \mathrm{Zn}$ per $100 \mathrm{~g}$ of dry weight) [Plessi et al., 1998].
Due to limited fresh market volumes compared to other soft berries, no larger studies on post-harvest techniques have been carried out on $R$. rubrum. Storage temperatures in the range of $0-1{ }^{\circ} \mathrm{C}$ combined with high values of relative humidity $(95 \%)$ have been suggested as optimum conditions in a normal atmosphere (NA) to maintain fresh berries for up to 3 weeks, but the evolution of biochemical properties is mainly associated with ripeness at harvest time and the cultivar. Management of the surrounding storage atmosphere ( 18 to $\left.20 \% \mathrm{CO}_{2}+2 \% \mathrm{O}_{2}\right)$ can extend the storage time [Agar et al., 1997; Roelofs \& Waart, 1993], but in some cultivars, high $\mathrm{CO}_{2}$ concentrations can result in physiological disorders, affecting berry colour and the internal breakdown [Roelofs \& Waart, 1993; Thompson, 1998]. Furthermore, some physiological disorders generally manifested by flesh browning and breakdown appear in berries stored with $\mathrm{CO}_{2}$ above $20 \%$. The modified atmosphere pallet system has been evaluated in the post-harvest storage of berries and other fruits as an alternative preserving technique [Giuggioli et al., 2019; Macnish et al., 2012; Peano et al., 2017] and is commercially available as a logistic solution to reduce fruit loss and optimise space in the warehouses of different fruit companies. The employment of active gas controlled-release pads or ethylene absorbers $\left(\mathrm{C}_{2} \mathrm{H}_{4}\right)$ can be positively associated with this technology to improve the success of storage management for different products. Red currants are not ethylene

\footnotetext{
* Corresponding Author: 
producers and are not susceptible to $\mathrm{C}_{2} \mathrm{H}_{4}$, but sulphur dioxide $\left(\mathrm{SO}_{2}\right)$ release pads could be positively associated with a modified atmosphere strategy to control the decrement of the overall quality and limit the microbial growth in berries [Ahmed et al., 2018; Saito et al., 2020]. Similarly to other berries, red currants are not washed during the supply chain process (harvesting, packing, and transportation); therefore, approved sanitisers, such as chlorine or sodium hypochlorite, cannot be added to control possible microbial contamination. The $\mathrm{SO}_{2}$-generating pads have largely been used in the post-harvest process of different fruits, such as table grapes [Ahmed et al., 2018; Carter et al., 2015; Ozkaya et al., 2008; Sortino et al., 2017; Zutahy et al., 2008], blueberries [Rodriguez \& Zoffoli, 2016; Saito et al., 2020], fragola [Hakimi et al., 2017], figs [Cantín et al., 2011], raspberries [Spayd et al., 1984], and lemons [Smilanick et al., 1995]. The amount of $\mathrm{SO}_{2}$ required to be effective is a function of the storage temperature and the time of release of $\mathrm{SO}_{2}$ of the emmittor used [Rivera et al., 2013]. A critical point that needs to be considered in $\mathrm{SO}_{2}$ treatment is the maximum absorption by the human body; the daily intake value permitted by the Joint FAO/WHO Expert Committee on Food Additives [JECFA, 2019] is 0-0.7 mg per $\mathrm{kg}$ of human body weight.

To improve the knowledge about post-harvest storage of red currants, which has so far been underreported in literature, the aim of this study was to evaluate the influence of an $\mathrm{SO}_{2}$ active storage system on the quality of $R$. rubrum berries stored for up to 60 days.

\section{MATERIALS AND METHODS}

\section{Fruit source and sample preparation}

Red currants ( $R$. rubrum cv. Rovada) were harvested in an orchard located at Peveragno (Cuneo, Piedmont, Italy) at the harvesting maturity stage and were free of decay or mechanical or insect injury. The currants were transported directly within 30 min to the Agrifrutta Cooperative warehouse (Peveragno, Cuneo, Piedmont, Italy) for sample preparation and storage. Selected fruits were packed in rigid ventilated polyethylene terephthalate (PET) open baskets containing $0.150 \mathrm{~kg}$ of fruit each. Ten PET baskets were placed in a cardboard flat. Eight flats were assembled in a single layer on a $100 \times 120 \mathrm{~cm}$ wood pallet base. A total of 20 layers of eight flats each were stacked onto a pallet commercial storage unit (Figure 1).

\section{Pallet treatments and storage conditions}

The red currants were sampled in two groups. The first group was palletised in an active modified atmosphere $\left(\mathrm{CO}_{2}\right.$-MAP treatment) and used as a control. The second group was palletised

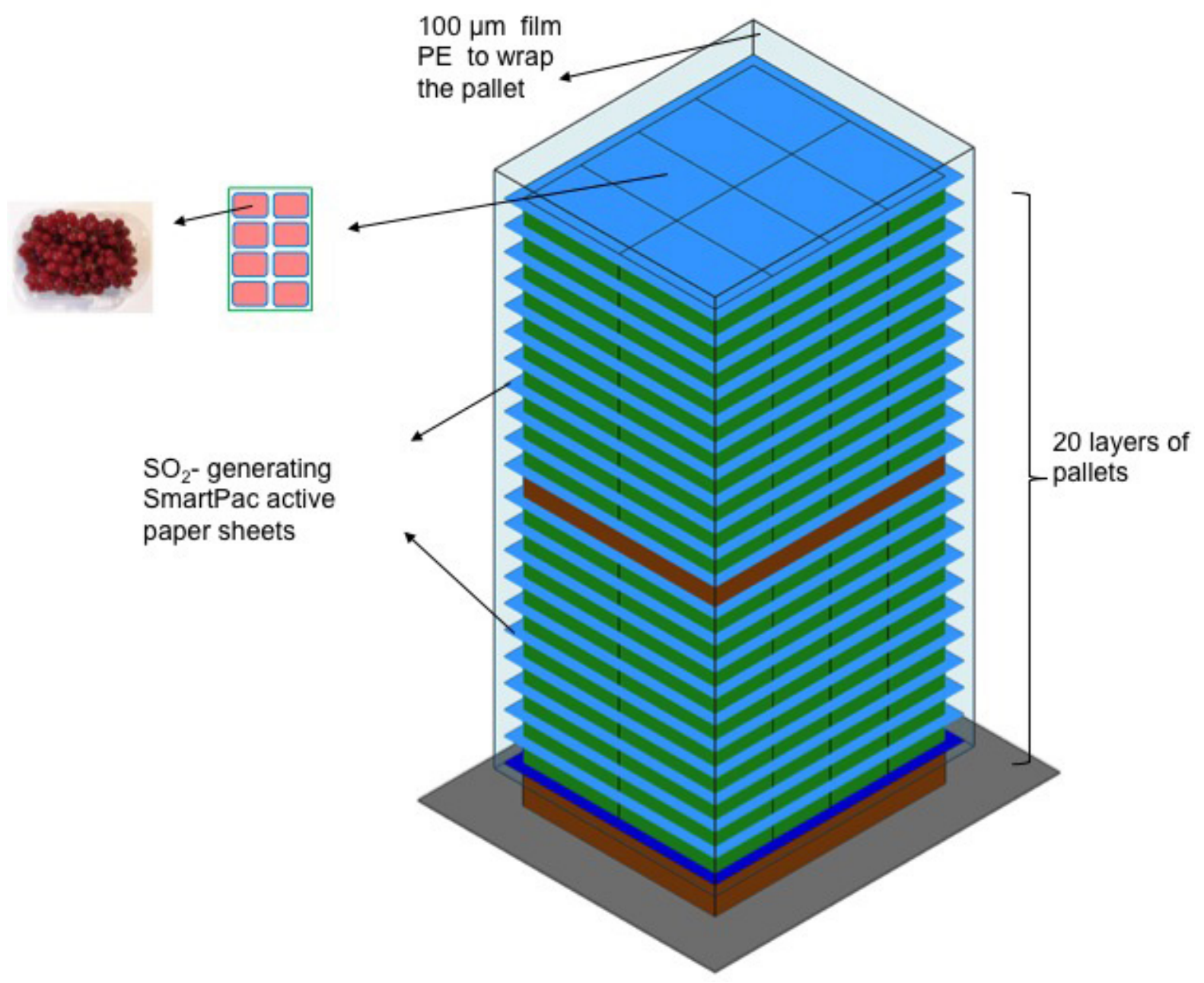

FIGURE 1. Design of the pallet unit used for storage of red currants in $\mathrm{SO}_{2}$ modified conditions. 
with $\mathrm{CO}_{2}+\mathrm{SO}_{2}$ ( $\mathrm{SO}_{2}-\mathrm{MAP}$ treatment). Each pallet was wrapped with a $100 \mu \mathrm{m}$ thick polyethylene film (PE) (thermally sealed at the base) with values of $\mathrm{O}_{2}\left(\mathrm{O}_{2} \mathrm{TR}\right)$ and $\mathrm{CO}_{2}\left(\mathrm{CO}_{2} \mathrm{TR}\right)$ transmission rates of $1572 \mathrm{~cm}^{3} / \mathrm{m}^{2} / \mathrm{d} /$ bar and $6111 \mathrm{~cm}^{3} / \mathrm{m}^{2} / \mathrm{d} /$ bar, respectively, measured at $23^{\circ} \mathrm{C}$ and at $50 \%$ relative humidity $(\mathrm{RH})$ with a MultiPerm oxygen and carbon dioxide analyser (Extra Solution s.r.l., Pisa, Italy) according to ASTM F 2622-08 and ASTM F 2476-05 standard guidelines [Briano et al., 2015].

The injection system for $\mathrm{CO}_{2}$-MAP treatment was operated as reported by Peano et al. [2017] to have initial gas values of $15.0 \mathrm{kPaO}_{2}$ and $10.0 \mathrm{kPa} \mathrm{CO}$. These values were based on previous experimental storage studies on red currants (data not published). The $\mathrm{SO}_{2}$-generating SmartPac active paper sheets (Serroplast, Bari, Italy) were applied directly to cover each of the total 20 layers stacked onto the storage unit pallet. All samples were stored for 60 days in a cold and dark room at $1 \pm 1^{\circ} \mathrm{C}$ and $90-95 \%$ RH. Data were collected at 0 (at the beginning of storage treatment), 30 (middle of the total storage time), and 60 days (long-term storage). For each treatment and storage time, three pallets were considered, sampling 30 random baskets in total. Figure 1 shows the experimental design of the pallet commercial unit.

\section{Pallet atmosphere and $\mathrm{SO}_{2}$ evaluation}

A gas analyser (CheckPoint II, PBI Dansensor, Milan, Italy) was used to measure the relative changes in the carbon dioxide and oxygen concentrations. The gas composition values were measured every 10 days over the trial period and were expressed in $\mathrm{kPa}$. The $\mathrm{SO}_{2}$ concentration was measured in ppm with dosimeter tubes (Gastec 5DH, Gastec Corporation, Ayase-City, Japan). The results were expressed as an average of three replicates.

\section{Weight loss and quality parameters}

Baskets were coded before the treatments. Weight loss (\%) was determined using an electronic balance (model SE622, VWR Science Education, Radnor, PA, USA), with a $10^{-2} \mathrm{~g}$ accuracy. Weight was monitored during the entire storage period and was calculated as the difference between initial $\left(\mathrm{W}_{0}\right)$ and final $\left(\mathrm{W}_{\mathrm{t}}\right)$ basket weights.

Weight loss $(\%)=\frac{\mathrm{W}_{0}-\mathrm{W}_{\mathrm{t}}}{\mathrm{W}_{\mathrm{n}}} \times 100$

The results were expressed as an average of 30 replicates.

After sample blending, the total soluble solids (TSS) were evaluated with a digital refractometer Atago® Pal-1 (Atago Co. Ltd., Tokyo, Japan) and expressed as ${ }^{\circ}$ Brix. For each quality control, the instrument was calibrated with distilled water. The titratable acidity (TA) was measured using an automatic titrator (Titritino 702, Methrom, Herisav, Switzerland), and determined potentiometrically using $0.1 \mathrm{~N} \mathrm{NaOH}$ to the end point of 7.0; it was expressed as g of malic acid equivalents per $100 \mathrm{~g}$ of berries [Djordjević et al., 2010].

Total anthocyanin content, total phenolic content, and antioxidant capacity

Twenty-five $\mathrm{mL}$ of an extraction solvent $(500 \mathrm{~mL}$ methanol, $23.8 \mathrm{~mL}$ deionised water, and $1.4 \mathrm{~mL} 37 \%$ hydrochloric acid) were added to $10 \mathrm{~g}$ of fruit. After $1 \mathrm{~h}$ storage in the dark at room temperature, the samples were thoroughly homogenised for $1 \mathrm{~min}$ with an Ultra-Turrax homogeniser (IKA, Staufen, Germany) and then centrifuged at $3,000 \times g$ for $15 \mathrm{~min}$. The supernatant obtained by centrifugation was collected, transferred into glass test tubes, and stored at $-20^{\circ} \mathrm{C}$ until analysis. The total phenolic content (TPC) was determined by visible spectrophotometry using the Folin-Ciocalteu reagent according to the method described by Slinkard \& Singleton [1977]. Gallic acid was used as a standard and absorbance of reaction mixtures was measured at $765 \mathrm{~nm}$. The results were expressed as mg of gallic acid equivalents per $100 \mathrm{~g}$ of fruit fresh weight (mg GAE/100 g fw). The total anthocyanin content (TAC) was quantified according to the $\mathrm{pH}$ differential method described by Cheng \& Breen [1991]. Anthocyanins were estimated by their absorbance (A) difference at 510 and $700 \mathrm{~nm}$ in buffers at $\mathrm{pH} 1.0$ and $\mathrm{pH} 4.5$, where $\mathrm{A}_{\text {tot }}=\left(\mathrm{A}_{515}-\mathrm{A}_{700}\right) \mathrm{pH} 1.0$ - $\left(\mathrm{A}_{515}-\mathrm{A}_{700}\right) \mathrm{pH}$ 4.5. The results were expressed as $\mathrm{mg}$ of cyanidin 3-O-glucoside (C3G) equivalents per $100 \mathrm{~g}$ of fruit fw. Antioxidant activity was determined as the ferric reducing antioxidant power (FRAP) following the methods of Pellegrini et al. [2003], with some modifications. The absorbance was read at $595 \mathrm{~nm} 4 \mathrm{~min}$ after the addition of appropriately diluted extracts or standard to the FRAP reagent. The results were expressed as mmol $\mathrm{Fe}^{2+}$ per $1 \mathrm{~kg}$ of fw of red currants. These analyses were performed with a UV-Vis spectrophotometer 1600 (PC VWR International, Milan, Italy).

\section{Microbial count determination}

Microbial evaluation was performed considering the count of total yeast, mould, and bacteria. Total yeasts and mould were examined according to the methods reported by the Compendium of Methods for the Microbiological Examination of Foods [Vanderzant \& Splittstoesser, 1992]. The same equipment used in a previous work on strawberry was applied [Chiabrando et al., 2018]. All plates were incubated at $30^{\circ} \mathrm{C}$ for 5 days. Three replicates were analysed, and the microbial counts were expressed as colony-forming units (CFU) per $\mathrm{g}$ of berry sample. Total aerobic bacteria (TAB) counts were determined according to ISO 4833-2 [2013]. Three replicates were analysed, and the microbial counts were expressed as colony-forming units (CFU) per g of berry sample.

\section{Sensorial evaluation}

Evaluation of the red currant fruits was also determined by means of sensory analysis, involving 10 panellists (five men and five women, 25-60 years old) who were previously trained using commercial berry samples. They received 15 bunches from each sample and provided sample descriptions based on consistency and taste (including sweet, acid, herbaceous, and astringent taste), and total aroma. All attributes were evaluated using a 9-point scale (ranging from 'very intense' as '9' to 'none' as ' 1 '). The taste test was performed $1 \mathrm{~h}$ after red currants were taken out of the stored pallet at room temperature $\left(20 \pm 1^{\circ} \mathrm{C}\right)$.

\section{Visual evaluation}

Visual evaluation was performed considering raceme and pedicel desiccation, healthy bunches, and visual quality. 
The same panellists as for sensory analysis were recruited. Healthy bunches were defined as the percentage of not damaged fruit. All attributes of freshness of the rachis and pedicels and the visual quality were scored using a 5-point scale. Desiccation scores were 1 = as green as at harvest; 2 = slight browning; 3 = browning but no shrivelling; 4 = browning and some shrivelling; and $5=$ dry and brown. Visual quality scores were $5=$ excellent, no defects; $4=$ very good, minor defects; 3 = fair, moderate defects; 2 = poor, major defects; and $1=$ unusable. Scores above 3 were considered unmarketable [Sortino et al., 2017].

\section{Statistical analyses}

All pooled data were analysed using SPSS Statistics 24 (2017, IBM, Milan, Italy) for MAC. Analysis of variance (ANOVA) was performed, followed by Tukey's post-hoc test $(p \leq 0.05)$, when the differences were significant.

\section{RESULTS AND DISCUSSION}

\section{Pallet atmosphere and $\mathrm{SO}_{2}$ evaluation}

MAP technology is well known to be applied as the most easy and convenient tool to extend shelf life and protect berries from external contaminants. The fruit respiration rate, storage temperature, and selectivity of the wrapping film to gas are key factors that contribute to maintaining the required gas composition. Changes in the storage atmosphere composition in the range of 18 to $20 \% \mathrm{CO}_{2}$ and $2 \% \mathrm{O}_{2}$ could be successful in extending the shelf life of $R$. rubrum up to 14 weeks [Thompson, 1998]. As reported in Figure 2, the initial gas composition in the different units of storage was $15.0 \mathrm{kPa} \mathrm{O}_{2}$ and $10.0 \mathrm{kPa} \mathrm{CO}_{2}$. A different trend was observed between the two MAP treatments. Considering $\mathrm{O}_{2}$, a general decrease was observed for each pallet system, even if it was more evident for the berries stored with only $\mathrm{CO}_{2}$. After 40 days of storage, the $\mathrm{O}_{2}$ content was under $5.0 \mathrm{kPa}$, achieving values of $1.5 \mathrm{kPa}$ at the end of storage. Berries stored with $\mathrm{SO}_{2}$ instead maintained values of $5.6 \mathrm{kPa}$ at the end of storage. The different concentrations of $\mathrm{O}_{2}$ could be explained by the increase of microbial counts (moulds and bacteria) in red currants stored with the MAP-CO treatments. As a consequence, different levels of $\mathrm{CO}_{2}$ were recorded among treatments. Up to 30 days, a similar evolution was monitored, then an increase of up to $15.0 \mathrm{kPa}$ (60 days) was achieved for the MAP-CO treatment stored pallets. In blueberries, Smilanick \& Henson [1992] reported concentration of $\mathrm{SO}_{2}$ in $100 \mathrm{ppm}$ at $0^{\circ} \mathrm{C}$ to control decay diseases. The success of $\mathrm{SO}_{2}$ treatments is a function of the time of exposure to gas multiplied by the concentration. $\mathrm{SO}_{2}$-generating SmartPac active sheets were active throughout the entire storage time; furthermore, the gas was recorded for up to 60 days (Figure 3). The highest concentration (20 ppm) was observed after 10 days of storage. Subsequent measurements recorded lower $\mathrm{SO}_{2}$ concentrations, achieving $0.8 \mathrm{ppm}$ at the end of storage, indicating effective adsorption from the surface of red currants.

\section{Weight loss and quality parameters}

The loss of marketable berries along the entire supply chain is registered at around 45\% [Temocico et al., 2014].
Weight loss is affected by water loss, which is the major cause of post-harvest deterioration and compromises the visual appearance, chemical content, and flavour of the product [Lufu et al., 2020]. Berry turgidity and raceme and stalk freshness are the main visual quality criteria for the final consumer, and their status is a function of the hydration of fruit tissues. As reported in Figure 4, both MAP treatments were able to limit the weight loss of red currants up to 60 days, and no statistically significant $(\mathrm{p}>0.05)$ differences were observed among the different treatments. Both $\mathrm{CO}_{2}$ and $\mathrm{SO}_{2}$ gas controlled weight loss to under $5 \%$, which can be considered the limit value for soft berries' marketability [Giuggioli et al., 2019]. Weight loss of the samples analysed in our study was in the range of $0.67-0.73 \%$ and $1.00-1.15 \%$ after 30 and 60 days of storage, respectively. The maintenance of high humidity around the stored berries thanks to MAP action limited the transpiration activity of red currants, and this is probably due to the proper water transmission rates of the PE film.

The total soluble solid (TSS) contents of fresh and stored red currants are shown in Table 1. The TSS content of fresh berries was in line with data reported by Djordjević et al. [2010]. Moreover, similarly to the results reported by Temocico et al. [2014], the change in atmospheric composition during storage did not affect the soluble solid content in all samples (Table 1). Storage for up to 60 days caused no significant ( $\mathrm{p}>0.05)$ decrease in the TSS content, moving from 10.9 ${ }^{\circ}$ Brix to $10.1^{\circ}$ Brix and $9.7^{\circ}$ Brix for $\mathrm{CO}_{2}$ and $\mathrm{SO}_{2}$ MAP treatments, respectively. No significant differences were observed

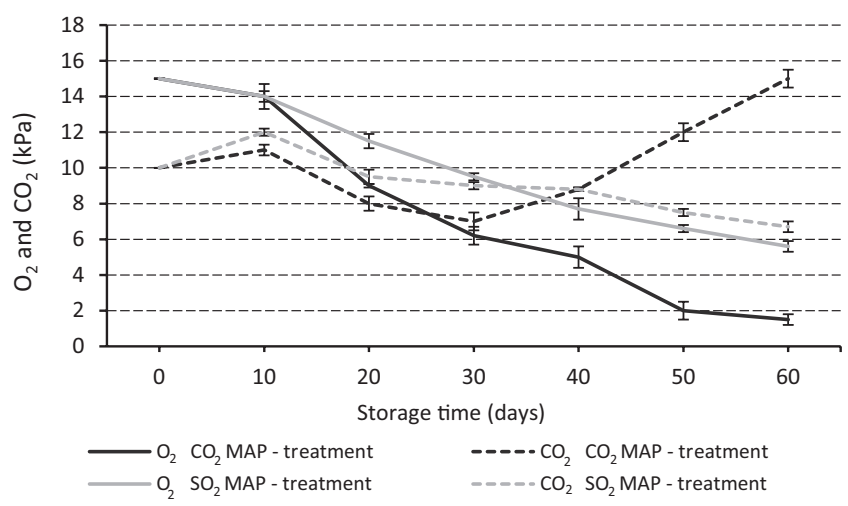

FIGURE 2. Gas evolution $\left(\mathrm{O}_{2}\right.$ and $\left.\mathrm{CO}_{2}\right)$ during red currants 60 days storage.

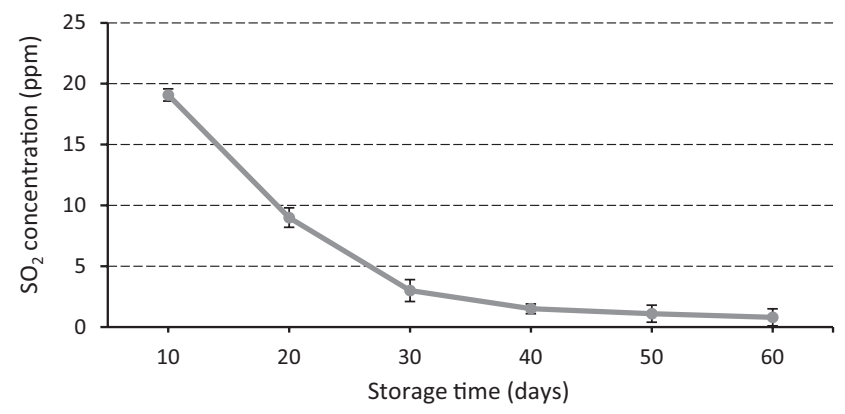

FIGURE $3 . \mathrm{SO}_{2}$ concentration during red currants 60 days storage under modified atmosphere packaging (MAP) conditions. 


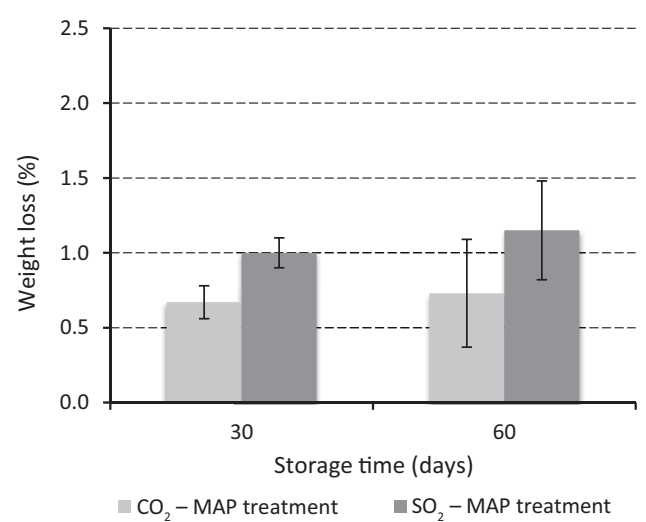

FIGURE 4. Weight loss of red currants during storage under modified atmosphere packaging (MAP) conditions.

among red currant samples exposed to $\mathrm{SO}_{2}$ and $\mathrm{CO}_{2}$ at the time, while differences $(\mathrm{p} \leq 0.05)$ were determined among MAP treatments only after 30 days of storage. Generally, $\mathrm{SO}_{2}$ and $\mathrm{CO}_{2}$ treatments, as observed on other fruits, did not affect the total soluble solid content during storage [Cantín et al., 2011, 2012]. The titratable acidity (TA) of red currants ranged from 1.2 to $1.0 \mathrm{~g} / 100 \mathrm{~g}$ fw at 60 days of storage, but TA changes during storage and differences between MAP treatments were not significant $(\mathrm{p} \leq 0.05)$ (Table 1$)$. Generally, losses of total acidity were reported to be accelerated by storage in elevated $\mathrm{CO}_{2}$ atmospheres [Harb \& Streif 2004]; in this case, the concentration of $\mathrm{CO}_{2}$ achieved in the stored pallet was appropriate for the maintenance of titratable acidity levels to values similar to those at harvest.

\section{Total anthocyanin content, total phenolic content, and antioxidant capacity}

The contents of phenolic compounds of fresh and stored red currants are reported in Table 2. The total anthocyanin content (TAC) of fresh fruits of cultivar Rovada was $22.1 \mathrm{mg}$ $\mathrm{C} 3 \mathrm{G} / 100 \mathrm{~g}$ fw. This value was in the range of $18-34 \mathrm{mg} / 100 \mathrm{~g} \mathrm{fw}$ as suggested by Benvenuti et al. [2004] for red currants grown in Italy and was lower than that recorded for cultivars grown in Finland (26.5-104 mg/100 g fw) [Mattila et al., 2016]. Among anthocyanins, red currants are rich in cyanidin glycosides including cyanidin 3-O-glucoside, cyanidin 3-O-sambusoside, cyanidin 3-O-rutinose, cyanidin 3-sophoroside, cyanidin 3-glucosylrutinoside, and cyanidin-3-xylosylrutinoside [Jara-Palacios et al., 2019; Mattila et al., 2016]. No statistically significant $(\mathrm{p}>0.05)$ differences were observed over time for each MAP treatment, and between treatments (Table 2). The total phenolic content (TPC) of red currant before storage was $233 \mathrm{mg} \mathrm{GAE} / 100 \mathrm{~g}$ fw, which is consistent with values reported in the literature [Laczkó-Zöld et al., 2018]. Similarly to anthocyanins, TPC showed the same evolution among samples over time, and statistically insignificantly lower content was determined in red currants under $\mathrm{SO}_{2}$ MAP storage. Storage atmospheres enriched in $\mathrm{CO}_{2}$ could prevent the increase in total antioxidant activity; however, the mechanism of control is still not clear, as no available data have been reported on the effect of $\mathrm{SO}_{2}$ on evolution of total antioxidant activity in red currants. The initial antioxidant capacity of fresh
TABLE 1. Total soluble solids (TSS) content and titratable acidity (TA) of red currants stored under modified atmosphere packaging (MAP) conditions.

\begin{tabular}{l|c|c|c|c}
\hline \multirow{2}{*}{ Parameter } & \multirow{2}{*}{ Treatment } & \multicolumn{3}{|c}{ Storage time (days) } \\
\cline { 3 - 5 } & & 0 & 30 & 60 \\
\hline \multirow{2}{*}{ TSS ( ${ }^{\circ}$ Brix $)$} & $\mathrm{CO}_{2}-\mathrm{MAP}$ & $10.9 \pm 0.5^{\mathrm{a} *}$ & $9.5 \pm 0.1^{\mathrm{aB}}$ & $10.1 \pm 0.3^{\mathrm{aA}}$ \\
& $\mathrm{SO}_{2}-\mathrm{MAP}$ & $10.9 \pm 0.5^{\mathrm{aA}}$ & $10.8 \pm 0.4^{\mathrm{aA}}$ & $9.7 \pm 0.6^{\mathrm{aA}}$ \\
& $\mathrm{CO}_{2}-\mathrm{MAP}$ & $1.2 \pm 0.1^{\mathrm{aA}}$ & $1.0 \pm 0.2^{\mathrm{aA}}$ & $1.0 \pm 0.1^{\mathrm{aA}}$ \\
TA $(\mathrm{g} / 100 \mathrm{~g})$ & $\mathrm{SO}_{2}-\mathrm{MAP}$ & $1.2 \pm 0.1^{\mathrm{aA}}$ & $1.1 \pm 0.2^{\mathrm{aA}}$ & $1.0 \pm 0.1^{\mathrm{aA}}$ \\
\hline
\end{tabular}

* Mean values with different lowercase letters within a row and capital letters within a column for each parameter measured are significantly different $(\mathrm{p} \leq 0.05)$

TABLE 2. Total anthocyanin content (TAC), total phenolic content (TPC), and ferric reducing antioxidant power (FRAP) of red currants stored under modified atmosphere packaging (MAP) conditions.

\begin{tabular}{|c|c|c|c|c|}
\hline & \multirow{2}{*}{ Treatment } & \multicolumn{3}{|c|}{ Storage time (days) } \\
\hline & & 0 & 30 & 60 \\
\hline \multirow{2}{*}{$\begin{array}{l}\text { TAC } \\
(\mathrm{mg} \mathrm{C} 3 \mathrm{G} / 100 \mathrm{~g} \mathrm{fw})\end{array}$} & $\mathrm{CO}_{2}-\mathrm{MAP}$ & $22.1 \pm 6.1^{1^{*}}$ & $20.5 \pm 9.2^{\mathrm{a}}$ & $27.4 \pm 11^{\mathrm{a}}$ \\
\hline & $\mathrm{SO}_{2}-\mathrm{MAP}$ & $22.1 \pm 6.1^{\mathrm{a}}$ & $19.7 \pm 1.6^{\mathrm{a}}$ & $17.2 \pm 4.3^{\mathrm{a}}$ \\
\hline \multirow{2}{*}{$\begin{array}{l}\text { TPC } \\
(\mathrm{mg} \text { GAE/100 g fw) }\end{array}$} & $\mathrm{CO}_{2}$-MAP & $233 \pm 11^{\mathrm{a}}$ & $267 \pm 20^{\mathrm{a}}$ & $203 \pm 21^{\mathrm{a}}$ \\
\hline & $\mathrm{SO}_{2}-\mathrm{MAP}$ & $233 \pm 11^{\mathrm{a}}$ & $70 \pm 18^{a}$ & $197 \pm 20^{\mathrm{a}}$ \\
\hline \multirow{2}{*}{$\begin{array}{l}\text { FRAP } \\
\left(\mathrm{mmol} \mathrm{Fe}{ }^{2+} / \mathrm{kg} \mathrm{fw}\right)\end{array}$} & $\mathrm{CO}_{2}-\mathrm{MAP}$ & $44.5 \pm 1.7^{\mathrm{a}}$ & $37.1 \pm 0.9^{b}$ & $36.9 \pm 1.1^{\mathrm{b}}$ \\
\hline & $\mathrm{SO}_{2}-\mathrm{MAP}$ & $44.5 \pm 1.7^{\mathrm{a}}$ & $35.8 \pm 1.1^{\mathrm{b}}$ & $34.6 \pm 1.2^{\mathrm{b}}$ \\
\hline
\end{tabular}

* Mean values in the row with different letters are significantly different $(\mathrm{p} \leq 0.05)$; GAE - gallic acid equivalents; $\mathrm{C} 3 \mathrm{G}$ - cyanidin 3 - $O$-glucoside equivalents; fw - fresh weight.

red currants was $44.5 \mathrm{mmol} \mathrm{Fe}{ }^{2+} / \mathrm{kg}$ fw. It is well known that the total anthocyanin and phenolic contents influence the antioxidant capacity in fruit [Orsavová et al., 2019]. Significant $(\mathrm{p} \leq 0.05)$ differences were observed for FRAP of stored red currants when compared with fresh berries.

\section{Microbial hazard evaluation}

The microbial population is an important factor that influences the quality and safety of fresh fruit [Mostafidi et al., 2020], and can be affected by different pre- and post-harvest sources. Clean pallets and sanitised containers during storage should be available for freshly harvested berries. The maintenance of the high humidity level required in storage makes red currants more susceptible to decay; therefore, sanitisation tools are necessary. MAP is generally considered a good technique to preserve fruits, and $\mathrm{CO}_{2}$ or other gasses, such as $\mathrm{O}_{3}$ and $\mathrm{SO}_{2}$, can minimise contamination due to the sanitiser effect of their molecules [Daeschel \& Udompijitkul, 2007]. Berries at picking (0 days) showed a microbial count of 13,000, 15,000, and 3,100 CFU/g for yeast, mould, and bacteria, respectively (Table 3). After that time, the two storage treatments showed different effects in terms of controlling 
TABLE 3. Microbial counts of red currants stored under modified atmosphere packaging (MAP) conditions.

\begin{tabular}{l|c|c|c|c}
\hline \multirow{2}{*}{ Microorganism } & \multirow{2}{*}{ Treatment } & \multicolumn{3}{c}{ Storage time (days) } \\
\cline { 3 - 5 } & & 0 & 30 & 60 \\
\hline \multirow{2}{*}{ Yeast (CFU/g) } & $\mathrm{CO}_{2}$-MAP & $13,000 \pm 465^{\mathrm{a}^{*}}$ & $22,000 \pm 1,200^{\mathrm{a}}$ & $6,000 \pm 115^{\mathrm{b}}$ \\
& $\mathrm{SO}_{2}$-MAP & $13,000 \pm 465^{\mathrm{a}}$ & $2,800 \pm 150^{\mathrm{b}}$ & $100 \pm 14^{\mathrm{c}}$ \\
\cline { 3 - 5 } Mould (CFU/g) & $\mathrm{CO}_{2}$-MAP & $15,000 \pm 330^{\mathrm{b}}$ & $17,000 \pm 930^{\mathrm{b}}$ & $100,000 \pm 980^{\mathrm{a}}$ \\
& $\mathrm{SO}_{2}$-MAP & $15,000 \pm 330^{\mathrm{b}}$ & $400 \pm 72^{\mathrm{c}}$ & $19,000 \pm 1,100^{\mathrm{a}}$ \\
\multirow{2}{*}{ Bacteria (CFU/g) } & $\mathrm{CO}_{2}$-MAP & $3,100 \pm 124^{\mathrm{b}}$ & $2,800 \pm 100^{\mathrm{b}}$ & $250,000 \pm 1,500^{\mathrm{a}}$ \\
& $\mathrm{SO}_{2}$-MAP & $3,100 \pm 124^{\mathrm{a}}$ & $100 \pm 25^{\mathrm{c}}$ & $1,500 \pm 88^{\mathrm{b}}$ \\
\hline
\end{tabular}

*Mean values in the row with different letters are significantly different $(\mathrm{p} \leq 0.05)$.

microbial evolution. $\mathrm{SO}_{2}$ was effective in controlling yeast evolution, reducing the population both at 30 and 60 days at one and two orders of magnitude, respectively. Less of an effect was observed for the $\mathrm{CO}_{2}$ treatment but only at 60 days. When berries were exposed to $\mathrm{SO}_{2}$, its dissolution into a water solution developed three molecular species, namely $\mathrm{SO}_{2}$ $\left(\mathrm{SO}_{2} \times \mathrm{H}_{2} \mathrm{O}\right)$, bisulphite $\left(\mathrm{HSO}_{3}{ }^{-}\right)$, and sulphite $\left(\mathrm{SO}_{3}{ }^{2-}\right)$ [Divol et al., 2012]. The toxic effect against yeast is mainly ascribed to $\mathrm{SO}_{2}$ because it has no charge; consequently, it should easily pass through the microbial cell membranes. Moreover, the high acidity and the low $\mathrm{pH}$ of red currants would be unfavourable to yeast intracellular processes [Divol et al., 2012]. Considering mould, no treatments successfully inhibited them for 60 days when compared to their presence at harvest (0 days). $\mathrm{SO}_{2}$ samples had 19,000 CFU/g, and $\mathrm{CO}_{2}$-treated samples had 100,000 CFU/g. The increase in the mould content in the control samples ( $\mathrm{CO}_{2} \mathrm{MAP}$ treatment) was probably due to the high humidity in the pallet system because it could not be adsorbed by the $\mathrm{SO}_{2}$-generating SmartPac active paper sheets. For the same reason, bacterial proliferation was also very high at 60 days of storage for the sample stored in $\mathrm{CO}_{2}$-MAP. Exposure to $\mathrm{SO}_{2}$ deeply reduced the initial bacterial microbial count $(3,100 \mathrm{CFU} / \mathrm{g}) ; 97 \%$ after 30 days and $52 \%$ after 60 days.

\section{Sensorial evaluation}

Sensorial quality was expressed by the personal preferences of the panellists, and the results are reported in Figure 5. Sensory studies on fresh red currants about the hedonistic overall quality are scarce in the literature, but it is well known that one of the most distinctive attributes of $R$. rubrum is the astringency of fruits, which is mainly affected by flavonol glycosides, derivatives of hydroxycinnamic acids, and various nitrous compounds [Schwarz \& Hofmann, 2007a,b]. At harvest (0 days) (Figure 5), red currants ranked a high score in terms of consistency attribute, astringent and acid taste, and total aroma, while the herbaceous and sweet taste were of moderate intensity. A similar profile in terms of sensorial properties among treatments was reported both at 30 (Figure 5A) and 60 days (Figure 5B), indicating that the gas $\left(\mathrm{CO}_{2}\right.$ and $\left.\mathrm{SO}_{2}\right)$ inside the MAP does not differentiate the taste of berries. In fact, after 30 and 60 days the same number
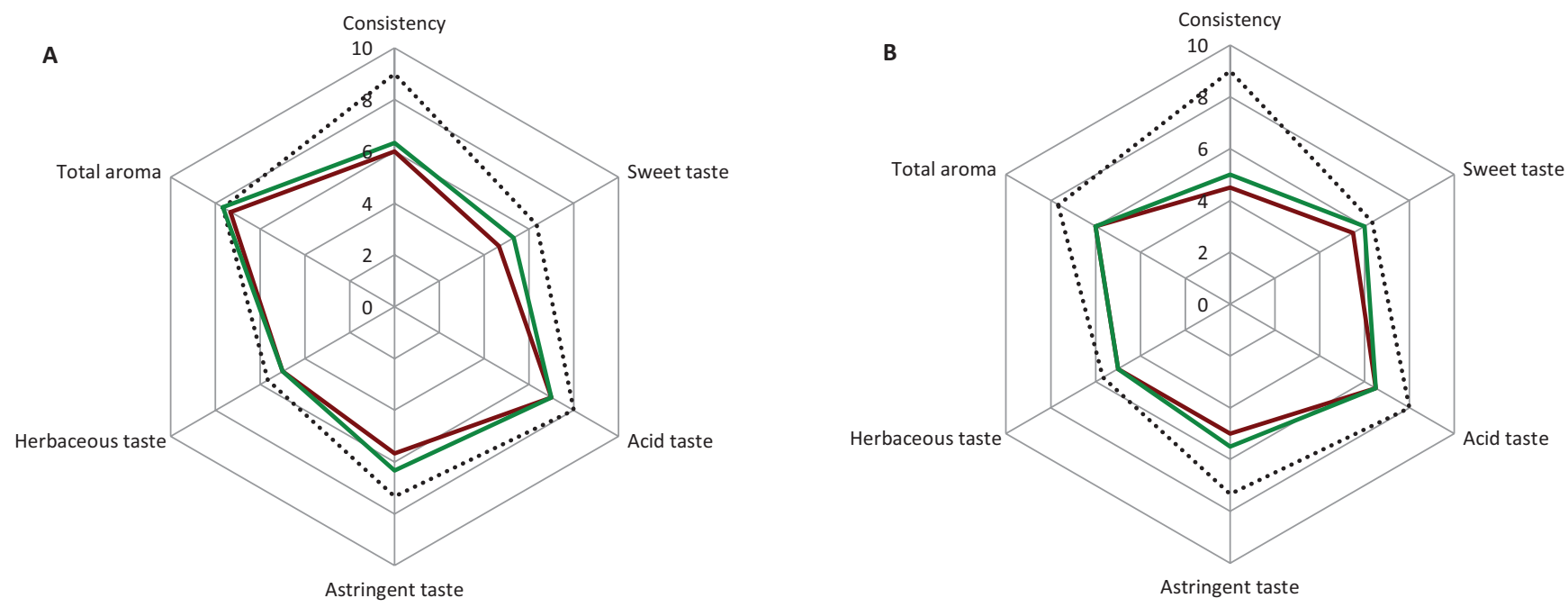

...... Fresh berries $\longrightarrow \mathrm{CO}_{2}$ MAP treatment $\longrightarrow \mathrm{SO}_{2}$ MAP treatment 


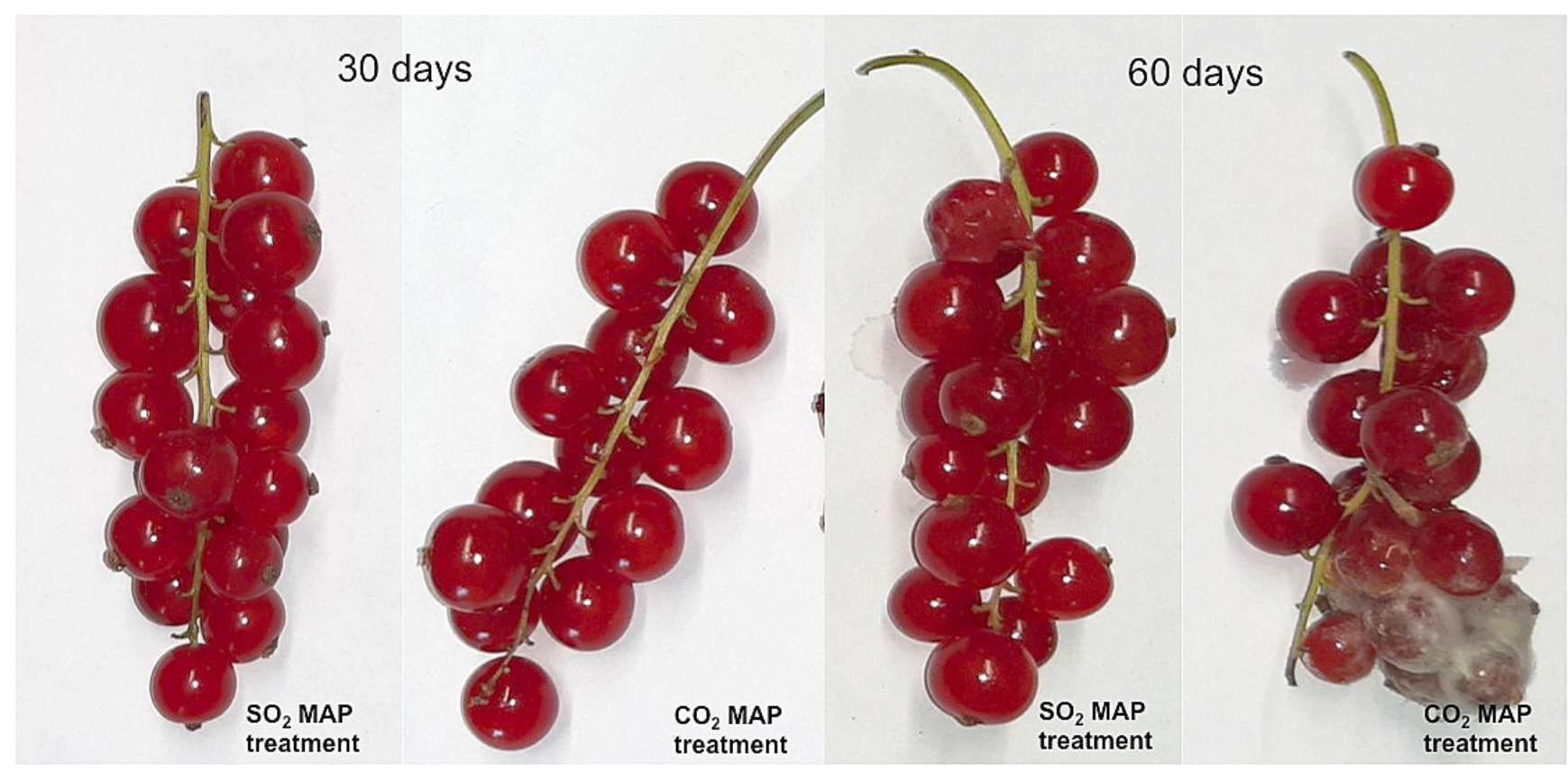

FIGURE 6. Red currants during the storage under modified atmosphere packaging (MAP) conditions.

of points were scored for acid (7.0 and 6.5) and herbaceous notes ( 5 both after 30 and 60 days), while for the others attributes no more than 0.5 of differences (no significant differences, $\mathrm{p}>0.05$ ) were scored. After 30 days, berries maintained the highest properties in terms of overall total aroma and acid taste. The perception by panel test decreased at 60 days, while the consistency had already changed (decreasing the score) during the short storage time (30 days). By observing the sensorial profile at the end of storage (60 days), it was possible to determine that astringent and acid notes of taste were the principal hedonistic indicators that influenced the overall acceptability of red currant cv. Rovada samples when stored. Sulphite residues are generally responsible for the decline in the flavour of fruit and affect consumers' willingness to fruit consumption [Shoaei et al., 2019]. However, in this study, there seemed to be no aversion to the red currants; in fact, a similar profile was observed between samples stored in $\mathrm{CO}_{2}$ and $\mathrm{SO}_{2} \mathrm{MAP}$.

\section{Visual evaluation}

The acceptance of fresh fruits in terms of marketability of the product was preliminary linked to an ideal visual appearance, which is expressed in terms of the absence of defects concerning external and internal parts of fruits, colour, and shape development. In red currants, a high number of berries per raceme, large and uniform fruits throughout the cluster, their complete red coloration, and the maintenance of a green raceme and pedicel are important visual quality criteria for the fresh market. Results of the visual evaluation of berries stored in $\mathrm{CO}_{2}$ and $\mathrm{SO}_{2}$ MAP treatments were expressed as raceme and pedicel desiccation, percentage of healthy bunches, and an overall visual quality (Table 4). Generally, the visual evaluation decreased over time, but red currants stored under $\mathrm{SO}_{2}$ MAP obtained better visual quality score compared to $\mathrm{CO}_{2}$ MAP treatment berries throughout storage. Figure 6 provides the images of red currants over storage.
TABLE 4. Parameters of visual evaluation of red currants stored under modified atmosphere packaging (MAP) conditions.

\begin{tabular}{l|c|c|c|c}
\hline Treatment & $\begin{array}{c}\text { Storage } \\
\text { time } \\
\text { (days) }\end{array}$ & $\begin{array}{c}\text { Raceme } \\
\text { and pedicel } \\
\text { desiccation }\end{array}$ & $\begin{array}{c}\text { Healthy } \\
\text { bunches (\%) }\end{array}$ & $\begin{array}{c}\text { Visual } \\
\text { quality }^{2}\end{array}$ \\
\hline Fresh berries & 0 & $5.0 \pm 0.0^{\mathrm{a} *}$ & $100 \pm 0.0^{\mathrm{a}}$ & $5.0 \pm 0.0^{\mathrm{a}}$ \\
$\mathrm{CO}_{2}$-MAP & 30 & $4.3 \pm 0.2^{\mathrm{b}}$ & $85 \pm 12^{\mathrm{a}}$ & $4.0 \pm 0.3^{\mathrm{b}}$ \\
$\mathrm{SO}_{2}$-MAP & 30 & $4.5 \pm 0.1^{\mathrm{b}}$ & $95 \pm 5.0^{\mathrm{a}}$ & $4.8 \pm 0.2^{\mathrm{a}}$ \\
$\mathrm{CO}_{2}$-MAP & 60 & $3.0 \pm 0.3^{\mathrm{c}}$ & $68 \pm 10^{\mathrm{c}}$ & $2.0 \pm 0.1^{\mathrm{d}}$ \\
$\mathrm{SO}_{2}$-MAP & 60 & $3.3 \pm 0.4^{\mathrm{c}}$ & $75 \pm 8.0^{\mathrm{b}}$ & $3.5 \pm 0.4^{\mathrm{c}}$ \\
\hline
\end{tabular}

*Means values in the column with different letters are significantly different $(\mathrm{p} \leq 0.05)$. 'Expressed in desiccation scores, were $1=$ as green as at harvest; $2=$ slight browning; $3=$ browning but no shrivelling; $4=$ browning and some shrivelling; and $5=$ dry and brown. ${ }^{2}$ Expressed in visual quality scores, were $5=$ excellent, no defects; $4=$ very good, minor defects; $3=$ fair, moderate defects; 2 = poor, major defects; and 1 = unusable.

\section{CONCLUSION}

Red currants are an interesting fruit belonging to the berries with a high potential in terms of health properties. The extent of the fresh market, which is still limited compared to those of other soft berries, such as blueberries or raspberries, needs to be supported by advances in post-harvest research. In this study, $R$. rubrum berries were stored at low temperatures under different MAP treatments, and external appearance traits, as well as internal quality properties, were examined for up to 60 days. Exposure to $\mathrm{SO}_{2}$ gas controlled microbial decay, resulting in a good visual appearance and promising maintenance of the most important sensorial attributes. Active emitters of $\mathrm{SO}_{2}$, such as those proposed, can be useful for the storage of red currants in extended storage after harvesting. 
Moreover, this technique could also be promising in the transport of red currants. Regardless of the bioactive compounds, future advances will be necessary regarding detailed phenolic composition to analyse and enhance this application.

\section{ACKNOWLEDGEMENTS}

We would like to thank the professionals, colleagues, and collaborators who actively participated in this research project.

\section{RESARCH FUNDING}

Research developed by the program ALTA FORMAZIONE IN APPRENDISTATO 2019-2022. Regione Piemonte (Art. 45-D. Lgs. N. 81/2015).

\section{ORCID IDs}

L. Brondino https://orcid.org/0000-0001-6476-9298

D. Cadario https://orcid.org/0000-0002-3473-3275

N.R. Giuggioli https://orcid.org/0000-0002-7532-5729

\section{REFERENCES}

1. Agar, I.T., Streif, J., Bangerth, F. (1997). Effect of high $\mathrm{CO}_{2}$ and controlled atmosphere (CA) on the ascorbic and dehydroascorbic acid content of some berry fruits. Postharvest Biology and Biotechnology, 11(1), 47-55.

https://doi.org/10.1016/S0925-5214(97)01414-2

2. Ahmed, S., Roberto, S.R., Domingues, A.R., Shahab, M., Chavez, Junior, O.J., Sumida, C.H., de Souza, R.T. (2018). Effects of different sulfur dioxide pads on Botrytis Mold in 'Italia' table grapes under cold storage. Horticulturae, 4(4), art. no. 29. https://doi.org/10.3390/horticulturae4040029

3. Benvenuti, S., Pellati, F., Melegari, M., Bertelli, D. (2004). Polyphenols, anthocyanins, ascorbic acid, and radical scavenging activity of Rubus, Ribes, and Aronia. Journal of Food Science, 69(3), FCT164-FCT169.

https://doi.org/10.1111/j.1365-2621.2004.tb13352.x

4. Briano, R., Giuggioli, N.R., Girgenti, V., Peano, C. (2015). Biodegradable and compostable film and modified atmosphere packaging in postharvest supply chain of raspberry fruits (cv. Grandeur). Journal of Food Processing and Preservation, 39(6), 2061-2073.

https://doi.org/10.1111/jfpp.12449

5. Cantín, C.M., Minas, I.S., Goulas, V., Jiménez, M., Manganaris, G.A., Michailides, T.J., Crisosto, C.H. (2012). Sulfur dioxide fumigation alone or in combination with $\mathrm{CO}_{2}$-enriched atmosphere extends the market life of highbush blueberry fruit. Postharvest Biology and Technology, 67, 84-91.

https://doi.org/10.1016/j. postharvbio.2011.12.006

6. Cantín, C.M., Palou, L., Bremer, V., Michailides, T.J., Crisosto, C.H. (2011). Evaluation of the use of sulfur dioxide to reduce postharvest losses on dark and green figs. Postharvest Biology and Technology, 59(2), 150-158.

https://doi.org/10.1016/j.postharvbio.2010.09.016

7. Carter, M.Q., Chapman, M.H., Gabler, F., Brandl, M.T. (2015). Effect of sulfur dioxide fumigation on survival of foodborne pathogens on table grapes under standard storage temperature. Food Microbiology, 49, 189-196.

https://doi.org/10.1016/j.fm.2015.02.002

8. Cheng, G.W., Breen, P.J. (1991). Activity of phenylalanine ammonia-lyase (PAL) and concentrations of anthocyanins and phenolics in developing strawberry fruit. Journal of the American Society of Horticultural Science, 116(5), 865-869.

https://doi.org/10.21273/JASHS.116.5.865

9. Chiabrando, V., Giuggioli, N., Maghenzani, M., Peano, C., Giacalone, G. (2018). Improving storability of strawberries with gaseous chlorine dioxide in perforated clamshell packaging. Polish Journal of Food and Nutrition Sciences, 68(2), 141-148.

https://doi.org/10.1515/pjfns-2017-0024

10. Daeschel, M.A., Udompijitkul, P. (2007). Microbial safety concerns of berry fruit. In Y. Zhao (Ed.) Berry Fruits Value Added Products for Health Promotion. Chapter 8, Taylor \& Francis Group, New York, USA, pp. 229-259.

https://doi.org/10.1201/9781420006148.ch8

11. Divol, B., du Toit, M., Duckitt, E. (2012). Surviving in the presence of sulphur dioxide: Strategies developed by wine yeasts. Applied Microbiology and Biotechnology, 95, 601-613.

https://doi.org/10.1007/s00253-012-4186-x

12. Djordjević, B., Šavikin, K., Zdunić, G., Janković T., Vulić, T., Oparnica, C., Radivojević, D. (2010). Biochemical properties of red currant varieties in relation to storage. Plant Foods for $\mathrm{Hu}$ man Nutrition, 65, 326-332.

https://doi.org/10.1007/s11130-010-0195-z

13. Fresh plaza: Poland the largest producer of currants in EU and second global. Available on-line: [www.freshplaza.com] (accessed: 15 November 2020).

14. Giuggioli, N.R., Briano, R., Baudino, C., Peano, C. (2019). Postharvest warehouse management of Actinidia arguta fruits. Polish Journal of Food and Nitrition Sciences, 69(1), 63-70. https://doi.org/10.31883/pjfns-2019-0006

15. Harb, J., Streif, J. (2014). Controlled atmosphere storage of highbush blueberries cv. 'Duke'. European Journal of Horticultural Science, 69(2), S. 66-72.

16. Hakimi, S.S., Sreenivas, K.N., Shankarappa, T.H., Krishna, H.C., Sadananda, G.K. (2017). Effect of sulphur dioxide pads on enhancement of shelf life of strawberry (Fragaria ananassa) under ambient condition. International Journal of Current Microbiology and Applied Sciences, 6(7), 2371-2377. https://doi.org/10.20546/ijcmas.2017.607.339

17. ISO 4833-2. (2003). Microbiology of food and animal feeding stuffs - Horizontal method for the enumeration of microorganisms. Colony-count technique at $30^{\circ} \mathrm{C}$.

18. Jara-Palacios, M.J., Santisteban, A., Gordillo, B. Hernanz, D., Heredia, F.J., Escudero-Gilete, M.L. (2019). Comparative study of red berry pomaces (blueberry, red raspberry, red currant and blackberry) as source of antioxidants and pigments. European Food Research Technology, 245, 1-9. https://doi.org/10.1007/s00217-018-3135-z

19. JECFA, Joint FAO/WHO Expert Committee on Food Additives (2019). 87th Meeting, Rome, Italy, World Health Organization \& Food and Agriculture Organization of the United Nations.

20. Laczkó-Zöld, E., Komlósi, A., Ülkei, T., Fogarasi, E., Croitoru, M., Fülöp, I., Domokos, E., Ştefănescu, R., Varga, E. (2018). Extractability of polyphenols from black currant, red currant and goose- 
berry and their antioxidant activity. Acta Biologica Hungarica, 69(2), 156-169.

https://doi.org/10.1556/018.69.2018.2.5

21. Lufu, R., Ambaw, A., Opara, U.L. (2020). Water loss of fresh fruit: influencing pre-harvest, harvest and postharvest factors. Scientia Horticulturae, 272, art. no. 109519. https://doi.org/10.1016/j.scienta.2020.109519

22. Kampuss K., Pedersen, H.L. (2003). A review of red and white currant (Ribes rubrum L.). Small Fruits Reviev, 2(3), 23-46. https://doi.org/10.1300/J301v02n03_03

23. Macnish, A.J., Padda, M.S., Pupin, F., Tsouvaltzis, P.I., Deltsidis, A.I., Sims, C.A., Brecht, J.K., Mitcham, E.J. (2012). Comparison of pallet cover systems to maintain strawberry fruit quality during transport. HortTechnology, 22(4), 493-501. https://doi.org/10.21273/HORTTECH.22.4.493

24. Mattila, P.H., Hellström, J., Karhu, S., Pihlava, J.M., Veteläinen, M. (2016). High variability in flavonoid contents and composition between different North-European currant (Ribes spp.) varieties. Food Chemistry, 204, 14-20.

https://doi.org/10.1016/j.foodchem.2016.02.056

25. Mostafidi, M., Sanjabi, M.R., Shirkhan, F., Zahedi, M.T. (2020). A review of recent trends in the development of the microbial safety fruits and vegetables. Trends in Food Science and Technology, 103, 321-332.

https://doi.org/10.1016/j.tifs.2020.07.009

26. Orsavová, J., Hlaváčová, I., Mlček, J., Snopek, L., Mišurcová, L. (2019). Contribution of phenolic compounds, ascorbic acid and vitamin $\mathrm{E}$ to antioxidant activity of currant (Ribes L.) and gooseberry (Ribes uva-crispa L.) fruits. Food Chemistry, 284, 323-333.

https://doi.org/10.1016/j.foodchem.2019.01.072

27. Ozkaya, O., Dundar, O., Ozdemir, A.E. (2008). Evaluation of ethanol and sulfur dioxide pad effects on quality parameters of stored table grapes. Asian Journal of Chemistry, 20(2), 1544-1550.

28. Peano, C., Giuggioli, N.R., Girgenti, V., Palma, A., D'Aquino, S., Sottile, F. (2017). Effect of palletized MAP storage on the quality and nutritional compounds of the Japanese Plum cv. Angeleno (Prunus salicina Lindl.) Journal of Food Processing and Preservation, 41 (2), art. no. e12786.

https://doi.org/10.1111/jfpp.12786

29. Pellegrini, N., Serafini, M., Colombi, B., Del Rio, D., Salvatore, S., Bianchi, M., Brighenti, F. (2003). Total antioxidant capacity of plant foods, beverages and oils consumed in Italy by three different in vitro assays. The Journal of Nutrition, 133(9), 2812-2819. https://doi.org/10.1093/jn/133.9.2812

30. Plessi, M., Bertelli, D., Rastelli, G., Albasini, A., Monzani, A. (1998). Fruits of Ribes, Rubus, Vaccinium and Prunus genus. Metal contents and genome. Fresenius' Journal of Analytical Chemistry, 361, 353-354. https://doi.org/10.1007/s002160050902

31. Rivera, S.A., Zoffoli, J.P., Latorre, B.A. (2013). Determination of optimal sulfur dioxide time and concentration product for postharvest control of gray mold of blueberry fruit. Postharvest Biology and Technology, 83, 40-46.

https://doi.org/10.1016/j. postharvbio.2013.03.007

32. Rodriguez, J., Zoffoli, J.P. (2016). Effect of sulfur dioxide and modified atmosphere packaging on blueberry postharvest quality. Postharvest Biology and Technology, 117, 230-238. https://doi.org/10.1016/j. postharvbio.2016.03.008
33. Roelofs, F.P.M.M., Waart, A.J.P. (1993). Long-term storage of red currants under controlled atmosphere conditions. Acta Horticulturae, 352, 217-222. https://doi.org/10.17660/ActaHortic.1993.352.31

34. Saito, S., Obenland, D., Xiao, C.L. (2020). Influence of sulfur dioxide-emitting polyethylene packaging on blueberry decay and quality during extended storage. Postharvest Biology and Technology, 160, art. no. 111045.

https://doi.org/10.1016/j.postharvbio.2019.111045

35. Schwarz, B., Hofmann, T. (2007a). Sensory guided decomposition of red currant juice (Ribes rubrum) and structure determination of key astringent compounds. Journal of Aricultural and Food Chemistry, 55(4), 1394-1404. https://doi.org/10.1021/jf0629078

36. Schwarz, B., Hofmann, T. (2007b). Isolation, structure determination, and sensory activity of mouth drying and astringent nitrogen containing phytochemicals isolated from red currants $(R i-$ bes rubrum). Journal of Agricultural and Food Chemistry, 55(4), 1405-1410.

https://doi.org/10.1021/jf0632076

37. Shoaei, F., Heshmati, A., Khorshidi, M. (2019). The risk assessment of sulphite intake through dried fruit consumption in Hamadan, Iran. Journal of Food Quality and Hazards Control, 6(3), 121-127.

https://doi.org/10.18502/jfqhc.6.3.1386

38. Slinkard, K., Singleton, V.L. (1977). Total phenol analysis: automation and comparison with manual methods. American Journal of Enology and Viticulture, 28(1), 49-55.

39. Smilanick, J.L., Henson, D.J. (1992). Minimum gaseous sulfur dioxide concentrations and exposure periods to control Botrytis cinerea. Crop Protection, 11(6), 535-540. https://doi.org/10.1016/0261-2194(92)90171-Z

40. Smilanick, J.L., Margosan, D.A., Henson, D.J. (1995). Evaluation of heated solutions of sulfur dioxide, ethanol, and hydrogen peroxide to control postharvest green mold of lemons. Plant Disease, 79, 742-747.

https://doi.org/10.1094/PD-79-0742

41. Sortino, G., Allegra, A., Passafiume, R., Gianguzzi, G., Gullo, G., Gallotta, A. (2017). Postharvest application of sulphur dioxide fumigation to improve quality and storage ability of "Red Globe" grape cultivar during long cold storage. Chemical Engineering Transaction, 58, 404-408. https://doi.org/10.3303/CET1758068

42. Spayd, S.E., Norton, R.A., Hayrynen, L.D. (1984). Influence of sulfur dioxide generators on red raspberry quality during postharvest storage. Journal of Food Science, 49(4), 1067-1069. https://doi.org/10.1111/j.1365-2621.1984.tb10393.x

43. Stępniowska, A., Czech, A., Malik, A., Chałabis-Mazurek, A., Ognik, K. (2016). The influence of winemaking on the content of natural antioxidants and mineral elements in wines made from berry fruits. Journal of Elementology, 21 (3), 871-880. https://doi.org/10.5601/jelem.2015.20.4.1020

44. Talcott, S.T. (2007). Chemical components of berry fruits. In Y. Zhao (Ed.) Berry Fruit Value Added Products for Health Promotion. Chapter 2, Taylor \& Francis Group, New York, USA, pp. 51-72. https://doi.org/10.1201/9781420006148

45. Thompson, A.K. (1998). Controlled Atmosphere Storage of Fruits and Vegetables. CAB Intl., Wallingford, UK. 
46. Temocico, G., Stoian, E., Ion, V., Tudor, V. (2014). Results regarding behaviour of some small fruits under controlled atmosphere conditions. Romanian Biotechnological Letters, 19(2), 9162-9169.

47. Vanderzant, C., Splittstoesser, D.F. (1992). Compendium of Methods for the Microbiological Examination of Foods. 3rd edition. American Public Health Association (APHA), Washington, USA.

48. Zutahy, Y., Lichter, A., Kaplunov, T., Lurie, S. (2008). Extended storage of 'Redglobe' grapes in modified $\mathrm{SO}_{2}$ generating pads. Postharvest Biolology and Technology, 50(1), 12-17.

https://doi.org/10.1016/j. postharvbio.2008.03.006 